\title{
History and current research in the field of radiochemistry at Maria Curie-Skłodowska University
}

\author{
Wladysław Rudziński • Andrzej Komosa
}

Published online: 13 February 2011

(C) The Author(s) 2011. This article is published with open access at Springerlink.com

\section{Introduction}

The year 2011 has been declared the International Year of Chemistry. This is also the 100th anniversary of awarding the Nobel Prize in Chemistry to Maria Curie-Skłodowska.

Maria Skłodowska, by marriage Curie, born and brought up in Poland, is one of the best known and most distinguished scientists. She is a patroness of many institutions, schools, scientific establishments, and universities not only at home but also abroad. Among them, Maria Curie-Skłodowska University occupies an important position.

To bring to mind the circumstances and reasons for its foundation, one should go 67 years into the past. It was 1944 and the Second World War was still in progress. However, in July that of year, Lublin became free from German occupation. Liberated Lublin attracted the intellectuals who had survived the turmoil of the war. Among the scientists who arrived in Lublin then was Henryk Raabe, the zoologist, a lecturer at Jagiellonian University and a professor at Lviv University, who on behalf of the scientific circle proposed the government should open a new university in Lublin. The first state university in Lublin,

Published in the special issue Radioanalytics - Dedicated to Marie Skłodowska-Curie with Guest Editors Boguslaw Buszewski and Philippe Garrigues.

\section{W. Rudziński}

Department of Theoretical Chemistry,

Maria Curie-Skłodowska University,

20-031 Lublin, Poland

\section{A. Komosa $(\triangle)$}

Department of Radiochemistry and Colloid Chemistry,

Maria Curie-Skłodowska University,

20-031 Lublin, Poland

e-mail: andrzej.komosa@umcs.lublin.pl
Maria Curie-Skłodowska University, was set up and started its activities on 23 October 1944 [1].

It can be presumed that the choice of the Lublin University patroness was made for two reasons. The world scientific prestige of the distinguished Pole was to highlight the status of the newly opened university. However, the reason might be the close family relationships of Maria Skłodowska with Lublin and the Lublin region. Her grandfather, Jozef Skłodowski, was the headmaster of the Province School in Lublin.

The first rector of the university was Henryk Raabe, who contributed greatly to its organization. The grand inauguration of the first academic year was held on 14 January 1945. Then, the new academic year was inaugurated on 23 October [1].

Since that time, Maria Curie-Skłodowska University in Lublin has been developing its own structure for meeting the academic standards and requirements resulting from changing scientific and social actuality. Presently, it includes ten faculties: arts; biology and earth sciences; economics; philosophy and sociology; humanities; mathematics, physics and computer science; pedagogy and psychology; law and administration; political science; as well as chemistry [2].

Situated in the center of the campus is the monument of the patroness, which watches over Maria Curie-Skłodowska University. It was unveiled in the centenary of the great chemist's birth. Thus, special attention is paid here to chemistry, which was inherent in her university from the very beginning although in various evolving institutional forms. Presently, in the Faculty of Chemistry about 280 people are employed, including 150 university teachers (43 hold the position of professor or lecturer) and the achievements of student education and research staff have resulted in about 3,500 graduates with the Master title in chemistry and environment protection, 246 scientists with the Doctor 
title in chemical science, and 78 members of habilitation studies who were granted the habilitation doctor title [3, 4].

The current organizational structure of the faculty is as follows:

- Department of Adsorption

- Department of Planar Chromatography

- Department of Physicochemistry of Solid Surfaces

- Department of Interfacial Phenomena

- Department of Analytical Chemistry and Instrumental Analysis

- Department of Inorganic Chemistry

- Department of General and Coordination Chemistry

- Department of Organic Chemistry

- Department of Polymer Chemistry

- Department of Environmental Chemistry

- Department of Chemical Technology

- Department of Theoretical Chemistry

- Department of Chemical Education

- Department of Crystallography

- Department of Chromatographic Methods

- Department for the Modeling of Physicochemical Processes

- Department of Optical Fiber Technology

- Department of Radiochemistry and Colloid Chemistry

In the Department of Radiochemistry and Colloid Chemistry investigations are carried out which are a continuation of the research done by Maria Curie, who after 1918 concentrated intensively on radiochemistry, that is, the chemistry of the radioactive elements: polonium, actinium, radium, and thorium isotopes.

The research of the department is colloid-chemistryoriented; particularly issues connected with generally understood surface physicochemistry, the ionic theory of double layers, and the stability of dispersed systems.

The other group of issues is widely understood environment protection, particularly radiochemical monitoring. These investigations started in 1986 after the nuclear power station disaster in Chernobyl. Presently, they include monitoring and study of the mechanism of radionuclide migration and accumulation in various areas with particular regard to adsorption of radioactive isotopes in soil, plants, bottom and alluvial sediments, as well as permanent monitoring of air and research into the presence of indoor radon.

\section{Radiotracer and radiochemical researches}

The first radioisotope laboratory in the Faculty of Chemistry was created in 1969. At the beginning it was intended to carry out various experiments in the field of physical chemistry using radioactive isotopes as tracers. These studies allowed the establishment of the reaction mechanisms of fine solid particle surfaces (mainly minerals) in connection with their flotation behavior [5].

Intensive study of flotation systems using radioisotope tracers and the development of didactic activity caused a transformation of the Isotope Laboratory into the Department of Radiochemistry and Application of Radioisotopes in 1974. The name of our department was changed again in 1983 when the additional scientific issues were introduced. The name Department of Radiochemistry and Colloid Chemistry has been used up till now.

At first, our department was equipped with a few Geiger-Müller and scintillation counters, which enabled beta and gamma radiation measurements of the radioactive tracers used.

These days, the scientific interest of our department is devoted to the physicochemistry of mineral enrichment by flotation, clarifying waste suspensions by the flocculation method, and dewatering of sediments using the agglomeration technique.

In particular, through the application of various radionuclides and isotope dilution techniques, studies on sorption mechanisms of flotation collectors have been performed. The selectivity of the chosen collectors was tested for various sulfide minerals such as galena, sphalerite, pyrite, marcasite, and chalcocite [6-10] and oxidized surface minerals such as calcite and zinc carbonates [11].

Adsorption of macromolecules onto the mineral surface with the aim to establish the stability of fine particle suspensions of minerals such as calcite, titanium dioxide, and hematite in the presence of polymer aqueous solutions was also a subject of our studies [12-17].

Simultaneously, applied research on dewatering of waste mineral suspensions (such as coal slimes from coal mines or remains after floatation enrichment of minerals) by means of the flocculation method in connection with the spherical agglomeration process was carried out [18-21]

Intensive development of radiochemical methods of analysis and determination of radionuclides in the environment proceeded after the Chernobyl disaster, which took place in 1986. It is marked as the greatest emergency on a seven-measure scale worked out by the International Atomic Energy Agency [22]. Erroneous decisions of operators together with unfavorable parameters of this type of work for such reactors led to damage of the reactor core. This resulted in the destruction of the reactor and release of large quantities of radioactive materials into the atmosphere, as well as the radioactive contamination of large regions, particularly in Europe.

The total release of radioactive substances was about $1.4 \times 10^{19} \mathrm{~Bq}$ (as of 26 April 1986), which included $1.8 \times$ $10^{18} \mathrm{~Bq}$ of ${ }^{131} \mathrm{I}, 8.5 \times 10^{16} \mathrm{~Bq}$ of ${ }^{137} \mathrm{Cs}$ and other cesium isotopes, $1 \times 10^{16} \mathrm{~Bq}$ of ${ }^{90} \mathrm{Sr}$, and $3 \times 10^{15} \mathrm{~Bq}$ of plutonium 
radioisotopes. Also noble gases were released in large amounts [23]. Most of the strontium and plutonium isotopes were deposited within a $100-\mathrm{km}$ zone around the reactor [23]. The most important isotopes are ${ }^{137} \mathrm{Cs},{ }^{90} \mathrm{Sr}$, ${ }^{238,239+240} \mathrm{Pu}$, and ${ }^{241} \mathrm{Am}$ [23], which have a rather long half-life.

The most airborne isotopes, such as ${ }^{131} \mathrm{I}$ and ${ }^{137} \mathrm{Cs}$, contaminated a large region of Europe, from which the deposition was highly heterogeneous. A characteristic trait of the Chernobyl contamination was the appearance of socalled hot spots, meaning fragments of the reactor core of several micrometers in diameter, containing highly radioactive isotopes, such as europium and promethium, and also plutonium, americium, and curium [24].

The Lublin region (eastern Poland) was at that time subjected to high radionuclide concentrations, which enabled the values to be monitored in a relatively easy way.

Our department systematically enlarged its measuring base by installing new spectrometric equipment for radionuclide determination of the environmental concentrations. As the Chernobyl fallout was formed of short-lived isotopes to a large extent, the observed radioactivity rather quickly came back to its "normal level." Artificial radioactivity present up till now is a result of the presence of ${ }^{137} \mathrm{Cs},{ }^{90} \mathrm{Sr}$, and plutonium. This is because these radionuclides have long half-lives.

In the course of the 24 years which have passed since the Chernobyl event, many multifaceted studies have been carried out, and a summary of the effects of the catastrophe has been presented in many reports by the IAEA and the Nuclear Energy Agency [23, 25]. In Poland, studies were also carried out on different issues related to the appearance and spreading of Chernobyl contamination. Such studies were also conducted in the Department of Radiochemistry and Colloid Chemistry. A brief summary of our results which reflected the current view of Chernobyl contamination in the Lublin region was presented in [26].

Presently, our department has two gamma spectrometers equipped with high-purity germanium detectors and the program Genie 2000 (Canberra), four alpha spectrometers with planar silicon detectors with a passivated surface (PIPS) with the same software, a liquid scintillation counter for labeled samples, and a Quantulus ultra-low-level liquid scintillation spectrometer. There is also equipment for radon measurements (Pico-Rad detectors) as well as determination of the concentration of radon and thoron daughters (automatic radon thoron daughters meter from Silena).

At the beginning our study on the presence of radionuclides in the environment focused on defining a radiological state of the environment-determination of the contamination level of soil, river, and lake sediments, as well as ground-level air with anthropogenic isotopes such as ${ }^{137} \mathrm{Cs},{ }^{90} \mathrm{Sr}$, and plutonium isotopes [27-37]. The occurrence of plutonium isotopes in ground-level air [3840] and indoor radon [41, 42] as well as radon in bottled mineral waters [43] was studied.

As a result of various phenomena occurring in the environment, the concentration of anthropogenic radionuclides is still diminishing. Therefore, as a continuation of the study on the radiological state of the environment, the study of radionuclide transport in soil profiles was undertaken [44-48].

Determination of lower concentrations of anthropogenic radionuclides demands, besides sufficiently sensitive equipment, also proper analytical procedures. Such procedures are necessary for determination of alpha-emitting isotopes $\left({ }^{238} \mathrm{Pu},{ }^{239+240} \mathrm{Pu}\right)$ and beta-emitting isotopes $\left({ }^{90} \mathrm{Sr} /{ }^{90} \mathrm{Y}\right.$ and ${ }^{241} \mathrm{Pu}$ ). In the Department of Radiochemistry and Colloid Chemistry, proper procedures were developed for radiochemical separation of the above-mentioned isotopes from environmental samples, where they are present at a very low level of activity. In this way, it was possible, for example, to measure the concentration of ${ }^{90} \mathrm{Sr},{ }^{239+240} \mathrm{Pu}$, and beta-emitting ${ }^{241} \mathrm{Pu}$ in subsequent layers of the soil profiles. This enabled us to calculate a vertical migration rate of the isotopes [46, 48-52].

The development of new and fast radioanalytical methods for the determination of radionuclides, especially those which are potentially hazardous in the case of uncontrolled radionuclide emission into the environment, is still a subject of our study. One of our recent interests is research on the method of determination of beta-radiating ${ }^{241} \mathrm{Pu}$. Plutonium is one of the most widely spread manmade radioactive elements in the environment. Its presence is a result of atmospheric nuclear tests being carried out intensively about 50 years ago. One of the possible methods of plutonium activity determination is using liquid scintillation spectrometry. This technique enables both alpha radiation measurements with very high efficiency and beta radiation measurements with efficiency dependent on energy. In all cases quenching is an important factor. With use of liquid scintillation spectrometry it is possible to determine alpha-radiating ${ }^{238} \mathrm{Pu},{ }^{239} \mathrm{Pu}$, and ${ }^{240} \mathrm{Pu}$ as well as beta-emitting ${ }^{241} \mathrm{Pu}$.

Plutonium determination in the environmental sample requires radiochemical treatment of the sample. The best method for this purpose is solvent extraction. Plutonium can be extracted from a matrix consisting of nonradioactive substances and, which is especially important, from radioactive uranium and thorium (present usually at relatively high concentrations). Selection of a suitable extracting agent with a high extraction yield and possible low quenching effect is very important. These questions are being investigated [53].

Owing to the radioanalytical methods described earlier, it was possible to determine plutonium isotopes in particular 
fractions extracted from soil and waste samples by the sequential extraction method. This method, named fractionation, allowed the determination of the bioavailability of radionuclides of interest despite their very low concentration not enabling speciation determination (as an ionic form or an oxidation state). Alpha-radiating plutonium isotopes, their determination, and their bioavailability in soils were subjects of our studies $[54,55]$.

Plutonium isotopes are present in the environment in a very low concentration and are not a hazard for human health. They are rather strongly bound with the surface soil layer and can be transferred to some degree into plants or can be resuspended in ground-level air. A chemical form of the isotope in soil is a main factor of its bioavailability. Because of the low concentration, it is difficult to determine speciation of plutonium. However, the fractionation method gives us information about the extent of plutonium binding with a specified fraction of defined characteristics. In this way, it is possible to estimate plutonium mobility in soil $[56,57]$.

Applying the sequential extraction method for the samples of surface soil from the Lublin region, we extracted five different fractions: easily available, exchangeable and carbonate bound, iron and manganese oxide bound, organic matter bound, and insoluble (not available). In all extracted fractions, plutonium isotopes were determined and their percentages calculated.

Several years ago a new research field was set up. It concerns the subject of radioecology with respect to birds which are in relations with other mammals. Birds can sometimes be treated as bioindicators of the environment. It is also relatively easy to collect proper experimental materials from dead birds. These birds are the victims of collisions with power lines, aerial masts, or high buildings in cities, and are brought to licensed veterinary clinics, where attempts at treatment are made. When and where treatment is not possible, or failed, injured birds are put to sleep to reduce their suffering. However, the period of time that these birds spend in veterinary clinics is no longer than 1 week. In a few cases, skeletons used in research were found during field surveys, thus at the place of death of a given bird.

Examination of the contamination of the bodies of birds and correlation of the results with their nestling places, migration routes, and feeding habits allowed us to assess the role of birds in contaminant transfer and to prove their role as environment bioindicators [58-60].

Modern spectrometers for radiation measurement which make use of the liquid scintillation technique are widely applied to determine beta-emitting radionuclides, especially those of low-energy radiation. A Quantulus (Wallac-PerkinElmer) spectrometer, owing to sophisticated electronics (amplitude comparator and anticoincidence systems) being an active system of background reduction, and passive shielding made of a large mass of lead, enabling very low activity of beta radiation to be measured, are used to determine beta-emitting radioisotopes occurring in the environment [61].

Preparation of environmental samples for alpha and beta radioisotope determination usually requires the application of multistage radiochemical separation procedures for isolation of the radionuclide to be determined. This is also the case when liquid scintillation spectrometry is used as a tool for radioactivity measurement. The final step of the radiochemical procedure usually involves solvent extraction of the radionuclide of interest. A sample obtained in this way is directly introduced into a scintillation cocktail. However, insufficient separation from contaminants present as matrix components causes a lowering of scintillation efficiency (so-called quenching). For this reason, the optimization of measurement conditions is an important factor in the determination of specific activity. Quenching is the main disadvantageous feature of liquid scintillation counting. The level of quenching is influenced by the chemical composition of the scintillation cocktail (whose precise composition is usually not known), the chemical composition of the sample, and the sample-to-cocktail volume ratio. There are many different scintillation cocktails available on the market, and they differ in their chemical composition and dedicated application to a given kind of sample [61]. Producers suggest for which kind of sample their cocktails are suitable. If one tries to utilize the cocktails for conditions other than those suggested, it is necessary to check what changes in measurement parameters this can introduce. These can cause various responses to quenching. Therefore, a study on optimization of measurement conditions of selected radionuclides using a number of commercial scintillation cocktails and various quenching levels was carried out $[62,63]$.

The aim of this paper is to present a history of radiochemistry research in the Department of Radiochemistry and Colloid Chemistry at Maria CurieSkłodowska University. The results of our studies in the fields of radiochemistry, radioecology, and radioanalytical methods and summarized data concerning the anthropogenic radioisotope contamination of the area of eastern Poland are now presented.

\section{Eastern Poland radioisotope contamination study}

Systematic studies of the contaminated environment of eastern Poland began several years after the Chernobyl disaster after measurement apparatus of appropriate quality (gamma spectrometers with germanium detectors and alpha spectrometers with silicon detectors) had been obtained. With use of this apparatus, research was carried out on the contamination of various components of the environment. 
The samples analyzed were collected according to IAEA [64] guidelines. The subjects of the studies were noncultivated soil samples, including forest soil and bog peat (in some cases cultivated soil was also analyzed), sediments from rivers and lakes, specified plants (grass, cultivated plants, pharmaceutical herbal plants), and bones and eggshells of birds.

The following anthropogenic isotopes were determined: ${ }^{137} \mathrm{Cs},{ }^{90} \mathrm{Sr},{ }^{238} \mathrm{Pu},{ }^{239+240} \mathrm{Pu}$, and ${ }^{241} \mathrm{Pu}$. Determination of each of these isotopes required appropriate preparation of samples, including radiochemical treatment necessary for qualitative and quantitative identification of isotopes emitting alpha and beta rays.

The measurement equipment and the procedures for preparing samples for determination of selected radionuclides are presented next.

Equipment and method for determination of gamma-radiating ${ }^{137} \mathrm{Cs}$

The material collected for gamma spectrometric measurement was dried and then mechanically crushed to a size of several millimeters in width (bones, plants) or $2 \mathrm{~mm}$ (sediments and soils). Small samples prepared in this way (about $20 \mathrm{~g}$ ) were placed on a flat container of 50-mm diameter and about $5-\mathrm{mm}$ height. Samples of appropriately large volume (about $500 \mathrm{~cm}^{3}$ ) were placed in Marinelli beakers.

The samples were subjected to spectrometric measurements performed with a gamma spectrometer (Canberra, Silena) equipped with a high-purity germanium detector of $87-\mathrm{cm}^{3}$ active volume, $17.5 \%$ relative efficiency, and 1.8 $\mathrm{keV}$ full width at half maximum (FWHM) resolution. A quantitative analysis was performed using Canberra Genie 2000 with the goal of determining the activity of natural and artificial radioactive isotopes.

Equipment and method for determination of alpha-radiating ${ }^{238} \mathrm{Pu}$ and ${ }^{239+240} \mathrm{Pu}$

Determination of plutonium in environmental samples requires separation of the isotopes in a pure form and fixing them on a steel plate, which enables alpha spectrometric measurements. This was achieved by a radiochemical multistage procedure. In the first stage of this procedure, a dried and ashed sample was leached with $6 \mathrm{M} \mathrm{HCl}$. From the solution obtained, trace elements were coprecipitated with iron(III) hydroxide by ammonia addition. The precipitate was dissolved in $6 \mathrm{M} \mathrm{HCl}$ and then separated from iron by coprecipitation with calcium oxalate. Next, the precipitate was dried, burned in an oven, dissolved in concentrated $\mathrm{HCl}$, and then a second coprecipitation with iron(III) hydroxide was performed. In the next stage, the precipitate was dissolved in $8 \mathrm{M}$
$\mathrm{HNO}_{3}$ and, after the oxidation state of plutonium had been changed to $\mathrm{Pu}^{4+}$, the solution was introduced onto an anion-exchange column (filled with Dowex $1 \times 8$ ) to separate plutonium from other trace elements. In the final stage, plutonium was eluted from the column using $\mathrm{HCl}$ with $0.1 \mathrm{M} \mathrm{NH}_{4} \mathrm{I}$. To obtain a sample suitable for alpha spectrometric measurement, plutonium was electrodeposited onto a stainless steel plate. Measurements were performed using a 7401 Canberra Alpha spectrometer with a 1520 mixer-router and an S-100 multichannel analyzer. The PIPS detector of 17-keV FWHM resolution was used. For quantitative analysis, Canberra Genie 2000 was applied. The chemical yield was monitored by the addition of a standard ${ }^{242} \mathrm{Pu}$ solution to the sample.

\section{Plutonium fractionation study}

Based on literature procedures for fraction isolation by sequential extraction $[56,65]$, the following procedure was applied in our study. The method involved the separation of the following fractions: (1) readily available fraction, extracted by $1 \mathrm{M}$ magnesium chloride; (2) carbonatebound fraction, extracted by acetic buffer (1 M sodium acetate/acetic acid); (3) hydrous iron and manganese oxide fraction, extracted by $0.04 \mathrm{M}$ hydroxylamine hydrochloride in $25 \%$ acetic acid; (4) oxidizable organically bound fraction, extracted by $0.02 \mathrm{M}$ nitric acid with hydrogen peroxide, then by $3.2 \mathrm{M}$ ammonium acetate in $20 \%$ nitric acid; (5) residual fraction extracted by boiling with $6 \mathrm{M}$ hydrochloride acid.

Extracted fractions were submitted for further radiochemical separation with the aim of purification of plutonium to measure its activity by alpha spectrometry. For this purpose a sample of every extracted fraction was acidified with hydrochloric acid and tracer ${ }^{242} \mathrm{Pu}$ and ferric ions as a carrier were introduced. Next, ammonia was added and ferric hydroxide was precipitated at $\mathrm{pH} 8$. After dissolution of the precipitate in $6 \mathrm{M}$ hydrochloric acid, a small amount of calcium ions and oxalic acid was added, then calcium oxalate was precipitated by changing the $\mathrm{pH}$ with ammonia. The next step involved destruction of oxalates by ashing, dissolution in $8 \mathrm{M}$ nitric acid, and coprecipitation of plutonium with ferric hydroxide. Further separation of plutonium isotopes was performed by the anion-exchange method and a sample for alpha spectrometric measurement was prepared by electrodeposition, as described earlier.

Equipment and method for determination of beta-radiating ${ }^{90} \mathrm{Sr}$ and ${ }^{241} \mathrm{Pu}$

Determination of beta-radioactive ${ }^{90} \mathrm{Sr}$ in environmental samples demands isolating it from other natural beta- 
emitting isotopes present in the sample materials. The procedure for separating this isotope was worked out by Solecki $[66,67]$ with the goal to determine its concentration by measurement using a liquid scintillation method. It consists in sample ashing, leaching with concentrated nitric acid, extracting yttrium ions from nitric acid solution (after adding the yttrium carrier) with tributyl phosphate, precipitating yttrium hydroxide using ammonia after dilution of the organic phase with ethanol, and purification of $\mathrm{Y}(\mathrm{OH})_{3}$ by dissolving the precipitate with nitric acid and adding a few grams of Dowex $1 \times 8$ resin into a bulk solution. Next, yttrium oxalate was precipitated and after it had been dissolved in nitric acid, ${ }^{210} \mathrm{~Pb}$ was removed by coprecipitation with $\mathrm{PbI}_{2}$. From the solution, yttrium oxalate was reprecipitated with the aim of yield determination by weight. Next, dry precipitate was suspended in water and added to the scintillation cocktail (Insta-Gel Plus, Packard) in a low-potassium standard glass vial. Measurements were made with the use of the Quantulus (Wallac-PerkinElmer) ultra-low-level spectrometer for $300 \mathrm{~min}$. The procedure applied allowed a minimum detectable amount of $0.02 \mathrm{~Bq} /$ $\mathrm{kg}$ to be obtained [66].

Beta-emitting ${ }^{241} \mathrm{Pu}$ was determined from the sample prepared for alpha spectrometric measurement. For this purpose, the stainless steel plate with plutonium electrolytically built up was treated with hot $4 \mathrm{M}$ nitric acid to remove plutonium into solution. Next, plutonium was extracted using $0.2 \mathrm{M}$ trioctylphosphine oxide solution in cyclohexane and the organic phase was transferred into a scintillation vial containing a Permablend III (Packard)/ toluene scintillation cocktail. Activity measurement was performed as described earlier using the liquid scintillation spectrometry technique.

\section{Results and discussion}

In the short period of several years after the Chernobyl catastrophe, it was possible to determine in the samples analyzed the activity of the gamma-emitting isotope ${ }^{134} \mathrm{Cs}$, which has a relatively short half-life (2.06 years). The entire quantity of this isotope was a result of Chernobyl residue. Therefore, knowing the ratio of cesium isotopes from the Chernobyl emission to be ${ }^{134} \mathrm{Cs} /{ }^{137} \mathrm{Cs}=0.528$ [23], we could calculate the participation of ${ }^{137} \mathrm{Cs}$ coming from this fallout in the entire concentration in the sample. The remaining quantity of ${ }^{137} \mathrm{Cs}$ present in the environment was the result of atomic bomb tests carried out to the greatest intensity in the 1960s. The possibility of distinguishing the source of ${ }^{137} \mathrm{Cs}$ (global or Chernobyl fallout) was lost at the moment when the ${ }^{134} \mathrm{Cs}$ activity fell below the level of minimum detection activity.
Analogously, testing the relation of the isotopic ratio ${ }^{238} \mathrm{Pu} /{ }^{239+240} \mathrm{Pu}$ in the samples, one can identify the participation of plutonium of Chernobyl origin. The participation of ${ }^{238} \mathrm{Pu}$ in global fallout was about $4 \%$; however, in the Chernobyl fallout, it was about $50 \%$. In the same way, one can calculate a value for the Chernobyl fraction of ${ }^{241} \mathrm{Pu}$ in the total concentration of ${ }^{241} \mathrm{Pu}$ in the sample [51].

The summarized results of our studies concerning determination of isotopes in various components of the environment are gathered in Tables 1, 2, 3, 4, 5 and 6, most often presented in the form of minimum and maximum values as well as arithmetic mean values and the year in which the measurements were made. Table 1 concerns ${ }^{90} \mathrm{Sr}$ determination $[49,60,66,68,69]$, Tables 2 and 3 concern determination of ${ }^{137} \mathrm{Cs}[31,47,48,60,66,69,71-74]$, Table 4 concerns determination of alpha-emitting plutonium isotopes [47, 48, 76], and Table 5 concerns betaemitting ${ }^{241} \mathrm{Pu}$ isotope $[51,77]$. Table 6 presents the vertical migration rate of plutonium isotopes [51].

The average global fallout of ${ }^{90} \mathrm{Sr}$ was $3,200 \mathrm{~Bq} / \mathrm{m}^{2}$, but up to the year 1986 (when additional amounts of this isotope were introduced into the atmosphere as a result of the Chernobyl disaster) it was lowered to $1,500 \mathrm{~Bq} / \mathrm{m}^{2}$ [70] as a result of the radioactive decay. Table 1 presents the average specific activities of ${ }^{90} \mathrm{Sr}$ in the surface soil and sediments of Bug River valley, in soil profiles of the Lake District in the Lublin region (noncultivated and arable soil), selected vegetables, pharmaceutical plants, and bones of birds of prey. As can be seen, the highest ${ }^{90} \mathrm{Sr}$ concentrations were found in the soil of Bug River, but they are still lower than the average value of fallout. It is interesting to note that the mean concentration of ${ }^{90} \mathrm{Sr}$ in soil profile layers of the Lake District is rather low and there is no marked difference between arable and noncultivated soil. Relatively high concentrations were observed in bones of birds. This is connected with nutrition preferences of these birds. They usually feed on small mammals living on the ground, and these can contain more ${ }^{90} \mathrm{Sr}$ in their bodies.

The results in Table 2 show that the radioactive fallout of ${ }^{137} \mathrm{Cs}$ on the eastern territories of Poland was relatively not homogeneous (large differences between the minimum and maximum values). Global fallout is considered rather as homogeneous; therefore, the observed nonhomogeneity comes from large participation of Chernobyl fallout in the entire fallout of ${ }^{137} \mathrm{Cs}$, reaching even $100 \%$, like in the case of the lake sediments. Then, the mean concentration of ${ }^{137} \mathrm{Cs}$ in the soil profile layers of the Lake District was low in comparison with other data for the surface soil. In the case of soil profiles, it was observed that ${ }^{137} \mathrm{Cs}$ concentration diminishes with the depth of the profile, as this nuclide migrates slowly down into the soil. The data presented in Table 2 are averaged values up to $20-\mathrm{cm}$ depth, which 
Table 1 Concentration of ${ }^{90} \mathrm{Sr}$ in the surface soil, soil profiles, and selected vegetable samples $[49,60,66,68,69]$ $d w$ dry weight

${ }^{a}$ Excluding one large result $(1.8 \mathrm{~Bq} / \mathrm{kg})$

\begin{tabular}{|c|c|c|c|c|}
\hline Sample & Minimum & Maximum & Mean $\pm \sigma$ & Year \\
\hline \multicolumn{5}{|l|}{ Surface soil } \\
\hline Soil of Bug River valley at the bank (Bq/kg) & 5.3 & 69.8 & $29 \pm 21$ & 1999 \\
\hline Soil of Bug River valley at the bank $\left(\mathrm{Bq} / \mathrm{m}^{2} / 10 \mathrm{~cm}\right)$ & 364 & 12,300 & $320 \pm 350$ & 1999 \\
\hline Soil of Bug River valley $(\mathrm{Bq} / \mathrm{kg})$ & 6.8 & 85.3 & $24 \pm 23$ & 1999 \\
\hline Soil of Bug River valley $\left(\mathrm{Bq} / \mathrm{m}^{2} / 10 \mathrm{~cm}\right)$ & 530 & 10,330 & $370 \pm 30$ & 1999 \\
\hline Bug River sediment (Bq/kg) & 3.7 & 20.5 & $10 \pm 5$ & 1999 \\
\hline \multicolumn{5}{|l|}{ Soil profiles (Lake District, north Lublin region) } \\
\hline \multicolumn{5}{|l|}{ Mean concentration in arable soil layers $(\mathrm{Bq} / \mathrm{kg})$} \\
\hline Profile 1 & 1.7 & 8.7 & $5.3 \pm 2.6$ & 2004 \\
\hline Profile 2 & 0.15 & 12 & $6.9 \pm 3.5$ & 2004 \\
\hline Profile 3 & 1.9 & 4.8 & $2.9 \pm 1.1$ & 2004 \\
\hline Profile 4 & 0.45 & 9.6 & $3.0 \pm 2.8$ & 2004 \\
\hline Profile 5 & 0.1 & 1.5 & $0.75 \pm 0.50$ & 2004 \\
\hline Profile 6 & 0.27 & 7.1 & $2.9 \pm 2.3$ & 2004 \\
\hline Profile 7 & 3.6 & 23 & $11 \pm 6.3$ & 2004 \\
\hline \multicolumn{5}{|l|}{ Mean concentration in noncultivated soil layers $(\mathrm{Bq} / \mathrm{kg})$} \\
\hline Profile 1 & 0.72 & 8.7 & $3.8 \pm 3.2$ & 2005 \\
\hline Profile 2 & 2.6 & 14 & $10 \pm 4.2$ & 2005 \\
\hline Profile 3 & 0.26 & 4.3 & $1.6 \pm 1.6$ & 2005 \\
\hline Profile 4 & 0.64 & 8.6 & $3.9 \pm 2.8$ & 2005 \\
\hline Profile 5 & 0.13 & 1.9 & $0.87 \pm 0.69$ & 2005 \\
\hline Profile 6 & 0.53 & 5.3 & $2.4 \pm 2.0$ & 2005 \\
\hline Profile 7 & 0.34 & 7.6 & $2.0 \pm 2.6$ & 2005 \\
\hline \multicolumn{5}{|l|}{ Vegetables } \\
\hline Potato Solanum tuberosum $(\mathrm{Bq} / \mathrm{kg} \mathrm{dw})$ & 0.09 & 2.4 & $1.0 \pm 0.9$ & 2004 \\
\hline Sugar beet Beta vulgaris $(\mathrm{Bq} / \mathrm{kg} \mathrm{dw})$ & 0.49 & 2.87 & $1.7 \pm 1.0$ & 2004 \\
\hline Carrot Daucus carota (Bq/kg dw) & 0.21 & 0.57 & $0.39 \pm 0.18$ & 2004 \\
\hline Grass (not specified) (Bq/kg dw) & 0.05 & 0.57 & $0.31 \pm 0.26$ & 2004 \\
\hline Birds of prey-bones ( 15 species, 57 individuals) & 4.6 & 15 & $8.8 \pm 3.4$ & 2005 \\
\hline Pharmaceutical herbal plants, 17 species $(\mathrm{mBq} / \mathrm{kg} \mathrm{dw})$ & 4 & 1810 & $140 \pm 120^{\mathrm{a}}$ & 2002 \\
\hline
\end{tabular}

corresponds to the soil layer with the largest radiocesium concentration.

In Table 3 radiocesium concentrations in selected plants, lichens, peat, and bird bones as well as eggshells are presented. The concentration of ${ }^{137} \mathrm{Cs}$ in one of the studied species of lichens from the family Parmeliaceae is about $50 \mathrm{~Bq} / \mathrm{kg}$. Similar quantities were observed also in the samples of peat and saw sedge, taken from the same territories of calcareous peat bogs. Lichens are considered biomonitors of contamination in the air, since most of their vital elements are taken from the atmosphere. Therefore, the observed contamination with ${ }^{137} \mathrm{Cs}$ points to their resuspension character.

The studied concentration of ${ }^{137} \mathrm{Cs}$ in bones and eggshells of the selected species of birds shows an interesting difference: the concentration in eggshells is 2-10 times higher than in bones. This is confirmation of the mecha- nism of removal of contaminants from the bird body into the eggshell.

The ${ }^{137} \mathrm{Cs}$ content in the eggshells of Montagu harriers, Circus pygargus, showed specific activity 4045 times lower in comparison with the concentrations found in saw sedge, Cladium mariscus, the plant in which the mentioned raptors nest. The concentrations in eggshells were also 27-43 times lower than those determined in the peat of marshes, the areas on which this plant grows [74]. The above observations indicate that transfer of ${ }^{137} \mathrm{Cs}$ from the environment to the tissues of the raptors from food comprising small mammals and insects related to the soil environment occurs to a very small extent. The determined mean specific activity of ${ }^{137} \mathrm{Cs}$ for all the birds studied was very low in comparison with that for the bones of other Polish raptors studied up to the present [75]. 
Table 2 Concentration of ${ }^{137} \mathrm{Cs}$ in the surface soil, profile samples, and sediments $[31,47,48,66,71]$

\begin{tabular}{|c|c|c|c|c|}
\hline Sample & Minimum & Maximum & Mean $\pm \sigma$ & Year \\
\hline \multicolumn{5}{|l|}{ Surface soil } \\
\hline Soil of Wieprz River valley at the bank $(\mathrm{Bq} / \mathrm{kg})$ & 237 & 4,460 & $1,620 \pm 910$ & 1998 \\
\hline Soil of Wieprz River valley $(\mathrm{Bq} / \mathrm{kg})$ & 588 & 3,730 & $1,750 \pm 840$ & 1998 \\
\hline \multicolumn{5}{|l|}{ Soil profiles (Lublin region), total activity } \\
\hline Brown soil (cambisol) $\left(\mathrm{Bq} / \mathrm{m}^{2}\right)$ & & & 4,500 & 1998 \\
\hline Lessive soil (luvisol) $\left(\mathrm{Bq} / \mathrm{m}^{2}\right)$ & & & 12,000 & 1998 \\
\hline Podzol soil (cambic podzol) $\left(\mathrm{Bq} / \mathrm{m}^{2}\right)$ & & & 5,200 & 1998 \\
\hline \multicolumn{5}{|l|}{ Soil profiles (Lake District, north Lublin region) } \\
\hline \multicolumn{5}{|l|}{ Mean concentration in arable soil $0-20 \mathrm{~cm}(\mathrm{~Bq} / \mathrm{kg})$} \\
\hline Profile 1 & 11.1 & 16.9 & $14.2 \pm 2.4$ & 2004 \\
\hline Profile 2 & 18.3 & 19.7 & $19.0 \pm 0.60$ & 2004 \\
\hline Profile 3 & 3.2 & 9.9 & $7.4 \pm 2.9$ & 2004 \\
\hline Profile 4 & 9.5 & 10.2 & $9.9 \pm 0.3$ & 2004 \\
\hline Profile 5 & 2.6 & 9.5 & $7.4 \pm 3.2$ & 2004 \\
\hline Profile 6 & 13.3 & 15.2 & $14.0 \pm 1.0$ & 2004 \\
\hline Profile 7 & 9.4 & 12.5 & $11.0 \pm 1.3$ & 2004 \\
\hline \multicolumn{5}{|c|}{ Mean concentration in noncultivated soil $0-20 \mathrm{~cm}(\mathrm{~Bq} / \mathrm{kg})$} \\
\hline Profile 1 & 3.6 & 33.3 & $19.8 \pm 15.7$ & 2005 \\
\hline Profile 2 & 4.7 & 12.7 & $9.0 \pm 3.3$ & 2005 \\
\hline Profile 3 & 14.6 & 20.7 & $18.2 \pm 2.9$ & 2005 \\
\hline Profile 4 & 6.2 & 15.4 & $11.5 \pm 3.8$ & 2005 \\
\hline Profile 5 & 7.4 & 12.3 & $10.9 \pm 2.7$ & 2005 \\
\hline Profile 6 & 6.0 & 21.3 & $13.2 \pm 6.3$ & 2005 \\
\hline Profile 7 & 4.8 & 10 & $7.8 \pm 2.4$ & 2005 \\
\hline \multicolumn{5}{|l|}{ Lake sediments (Lake District, north Lublin region) } \\
\hline Piaseczno Lake (Bq/kg dw) & 0.7 & 240 & $77 \pm 68$ & 1995 \\
\hline Masluchowskie Lake (Bq/kg dw) & 3.5 & 290 & $100 \pm 94$ & 1995 \\
\hline Zemborzycki artificial lake (Bq/kg dw) & 1.0 & 53 & $24 \pm 18$ & 1995 \\
\hline Wieprz River $(\mathrm{Bq} / \mathrm{kg} \mathrm{dw})$ & & & 6.9 & 1995 \\
\hline
\end{tabular}

Table 3 Concentration of ${ }^{137}$ $\mathrm{Cs}(\mathrm{Bq} / \mathrm{kg})$ in selected lichen, bird bones and eggshells, plant, and peat samples $[31,60,69$, 72-74]

${ }^{\text {a }}$ Excluding three very large results (3.4, 5.5, and $9.8 \mathrm{~Bq} / \mathrm{kg}$ )

\begin{tabular}{lllll}
\hline Sample & Minimum & Maximum & Mean $\pm \sigma$ & Year \\
\hline Lichens (Parmeliaceae), 15 samples & 2.6 & 108 & $46 \pm 29$ & 1998 \\
Pharmaceutical herbal plants, 17 species (mBq/kg dw) & 53 & 9850 & $346 \pm 263^{\mathrm{a}}$ & 2002 \\
Birds of prey_bones (15 species, 57 individuals) & 1.1 & 27 & $5.4 \pm 6.8$ & 2005 \\
Birds - eggshell & & & & \\
Grey heron Ardea cinerea (4 samples) & 4.9 & 16.1 & $10.4 \pm 4.6$ & 2003 \\
Mute swan Cygnus olor (13 samples) & 3.3 & 112 & $27.4 \pm 31.3$ & 2003 \\
Montagu harrier Circus pygargus (6 samples) & 15 & 40 & $29.4 \pm 10.7$ & 2003 \\
Marsh harrier Circus aeruginosus (4 samples) & 44 & 71 & $54.7 \pm 11.5$ & 2003 \\
Saw sedge Cladium mariscus (Chelm, eastern Poland) & & & & \\
Sampling point A & & & $56.9 \pm 0.7$ & 2005 \\
Sampling point B & & & $48.5 \pm 0.5$ & 2005 \\
Peat (Chelm, eastern Poland) & & & $33.7 \pm 0.9$ & 2005 \\
Sampling point A & & & $53.2 \pm 1.3$ & 2005 \\
Sampling point B & & & & \\
\hline
\end{tabular}


Table 4 Concentration of ${ }^{239+240} \mathrm{Pu}(\mathrm{mBq} / \mathrm{kg})$ in various samples and its Chernobyl fraction $[47,48,76]$

\begin{tabular}{|c|c|c|c|c|c|}
\hline Sample & Minimum & Maximum & Mean $\pm \sigma$ & Chernobyl (\%) & Year \\
\hline Surface soil of Lublin region $(0-2 \mathrm{~cm}), 9$ samples & 80 & 340 & $210 \pm 80$ & 15 & 1993 \\
\hline Lake sediment & 10 & 650 & $2,600 \pm 100$ & & 1995 \\
\hline Forest soil profiles $(0-45 \mathrm{~cm})\left(\mathrm{Bq} / \mathrm{m}^{2}\right)$ & 60 & 335 & $40.4-61.2$ & $0.7-2.9$ & 1996 \\
\hline Lublin river sediments, 14 samples & 70 & 315 & $50 \pm 36$ & 17 & 1996 \\
\hline Soil of Wieprz River valley at the bank & 20 & 65 & $150 \pm 15$ & $2-15$ & 1998 \\
\hline Soil of Wieprz River valley & 10 & 420 & $160 \pm 15$ & $3-23$ & 1998 \\
\hline Wieprz River sediment & 10 & 200 & $40 \pm 10$ & $2-27$ & 1998 \\
\hline Soil of Bug River valley at the bank & & & $170 \pm 20$ & $2-60$ & 1999 \\
\hline Bug River sediment & & & $60 \pm 5$ & $35-70$ & 1999 \\
\hline Soil of Wieprz River valley $\left(\mathrm{Bq} / \mathrm{m}^{2}\right)$ & & & $4-21$ & $2-15$ & 1998 \\
\hline \multicolumn{6}{|l|}{ Saw sedge Cladium mariscus (Chelm, eastern Poland) } \\
\hline Sampling point $\mathrm{A}$ & & & $46.7 \pm 10.8$ & & 2005 \\
\hline Sampling point B & & & $34.8 \pm 23.1$ & & 2005 \\
\hline \multicolumn{6}{|l|}{ Peat (Chelm, eastern Poland) } \\
\hline Sampling point $\mathrm{A}$ & & & $450 \pm 78$ & & 2005 \\
\hline Sampling point B & & & $361 \pm 27$ & & 2005 \\
\hline
\end{tabular}

As can be noticed in Table 4, the average value of ${ }^{239}$ ${ }^{+240} \mathrm{Pu}$ in the soil is about $200 \mathrm{mBq} / \mathrm{kg}$; the concentration of plutonium in lake sediments exceeds this value by 10 times; however, in river sediments it is about 4 times lower. Taking into account the same mechanism for the transfer of radionuclides from soil to water, we can suppose that the lack of water flow in the case of lakes does not allow for removal of radionuclides coming into the water. In this way, plutonium entering the water after a certain time is accumulated in the bottom sediment in quantities depending on the distribution coefficient of the radionuclide between the water phase and the sediment, including the subsequent chemical reactions such as complexation, coprecipitation, and radiocolloid formation. Similar behavior was also observed in the case of ${ }^{137} \mathrm{Cs}$, an anthropogenic element coming from global and Chernobyl fallout [47, 48]. Both of these elements, being the result of human activity, are closely bound to the upper layer of soil. Therefore, they do not easily enter the water phase, even after their long-term contact with soil (as a result of occasional flooding of river valleys).

It is interesting to compare the quantity of Chernobyl fractions of ${ }^{239+240} \mathrm{Pu}$ in the samples coming from the Wieprz River and Bug River valleys, despite the relatively large error associated with calculating this fraction. The average participation of the Chernobyl ${ }^{239+240} \mathrm{Pu}$ in soils and bottom sediment of the Wieprz was about $8 \%$, and in the case of the Bug it reached about $35 \%$. This difference can be tied to the fact that the Bug flows through the territories that were exposed to Chernobyl fallout to a greater extent.
Table 5 Concentration of ${ }^{241} \mathrm{Pu}$ in the soil samples and its Chernobyl fraction (calculated on the date of the Chernobyl disaster) [51, 77]

${ }^{\text {a }}$ Values calculated in March 2007

\begin{tabular}{llll}
\hline Sample & Mean $\pm \sigma$ & Chernobyl (\%) & Year \\
\hline Surface soil (0-10 cm) & & \\
Soil of Lublin region, 8 samples (Bq/kg) & $0.95 \pm 0.54$ & & 2000 \\
Forest soil of Lublin region (Bq/kg) & $5.4 \pm 0.7$ & & 2000 \\
Cultivated soil profiles (Lake District, north Lublin region) & & \\
Summarized fallout in the profile 0-40 cm (Bq/m²) & & \\
Profile 1 & $1,040 \pm 40$ & 96.9 & 2007 \\
Profile 2 & $610 \pm 10$ & 99.7 & 2007 \\
Profile 3 & $530 \pm 10$ & 84.0 & 2007 \\
Profile 4 & $460 \pm 10$ & 89.9 & 2007 \\
Profile 5 & $390 \pm 10$ & 76.1 & 2007 \\
Profile 6 & $320 \pm 10$ & 67.9 & 2007 \\
\hline
\end{tabular}


Table 6 Mean migration rate of plutonium isotopes in soils calculated separately for the global and Chernobyl fractions [51]

\begin{tabular}{|c|c|c|c|}
\hline \multirow[t]{2}{*}{ Sample } & \multicolumn{2}{|c|}{ Plutonium fallout fractions } & \multirow[t]{2}{*}{ Year } \\
\hline & Global (cm/year) & Chernobyl (cm/year) & \\
\hline \multicolumn{4}{|l|}{${ }^{239+240} \mathrm{Pu}$} \\
\hline Surface soil from east Poland $(0-10 \mathrm{~cm}), 40$ samples & $0.55 \pm 0.16$ & $1.58 \pm 0.80$ & 1996-1998 \\
\hline \multicolumn{4}{|l|}{ Cultivated soil (Lake District, north Lublin region) } \\
\hline 6 soil profiles $0-20 \mathrm{~cm}$ & $0.64 \pm 0.17$ & $1.92 \pm 0.69$ & 2006 \\
\hline 14 soil profiles $0-15 \mathrm{~cm}$ & $0.57 \pm 0.27$ & & 2008 \\
\hline \multicolumn{4}{|l|}{${ }^{241} \mathrm{Pu}$} \\
\hline \multicolumn{4}{|l|}{ Cultivated soil (Lake District, north Lublin region) } \\
\hline 6 soil profiles $0-20 \mathrm{~cm}$ & $0.67 \pm 0.18$ & $1.54 \pm 0.65$ & 2007 \\
\hline
\end{tabular}

The relatively large contamination of peat with plutonium isotopes is connected with its large surface area and high concentration of humic substance, a compound which easily binds plutonium.

In Table 5 the concentration of beta-radioactive ${ }^{241} \mathrm{Pu}$ in soil is presented and the Chernobyl fraction of this isotope is shown as well. As expected, the mean concentration of ${ }^{241} \mathrm{Pu}$ is a few times larger than that of ${ }^{239+240} \mathrm{Pu}$, which is related to the isotopic ratio of the fallout. It is interesting to see that the Chernobyl fraction of this isotope is almost $100 \%$. This means that, in contrast to ${ }^{239+240} \mathrm{Pu}$, beta-radiating ${ }^{241} \mathrm{Pu}$ is mainly of Chernobyl origin.

Further study on the migration rate of plutonium isotopes allowed us to calculate the velocity of vertical plutonium transport in soil profiles. The results are summarized in Table 6. As shown, the mean migration rate is relatively low. A difference between the Chernobyl and global origin of plutonium is also observed. As a rule, the Chernobyl plutonium migrates 3 times more quickly than the global fallout plutonium. This is probably connected to different chemical forms of plutonium in these two types of fallout.

As a result of the fractionation study of plutonium isotopes in soil, it was found that in arable soil about $45-60 \%$ of plutonium is bound with easily available and carbonate (also available if the $\mathrm{pH}$ of the soil is a little lowered) fractions. Only a small percentage of plutonium was bound permanently as an insoluble fraction. In contrast, in noncultivated soil, most plutonium was bound with an organic fraction, more than $10 \%$ is permanently bound, and only a small percentage is available.

\section{Conclusions}

Among the main classes of environmental contaminants, radionuclides tend to be generally less known and less frequently studied than heavy metals or organic compounds. This is because the problem of radioactive contaminants concerned a small number of regions to which, on account of military matters, there was limited access. However, this changed after the disastrous explosion of the Chernobyl nuclear reactor.

As shown, global fallout contamination is still important in eastern Poland, as well Chernobyl fallout. The anthropogenic radionuclides can still be found and determined in the environment. The global character of both fallouts, their accumulation in natural as well as transformed ecosystems, and their transportation through biotic and abiotic pathways made them a subject of interest for research while taking advantage of various models. Therefore, our department became involved in such a study and the study will continue and be developed further.

Open Access This article is distributed under the terms of the Creative Commons Attribution Noncommercial License which permits any noncommercial use, distribution, and reproduction in any medium, provided the original author(s) and source are credited.

\section{References}

1. Malarczyk J (ed) (1968) Formation and organization of Maria CurieSklodowska University in the light of the source documents. Lublin

2. Glinski J, Malarczyk J, Pollo I, Prost EK, Wielgus S (eds) (1994) In: Fiftieth anniversary of establishment of Maria CurieSklodowska University. Lublin Scientific Society, Lublin

3. Goworek J, Kozioł A, Gęca T (eds) (2005) Faculty of chemistry. UMCS, Lublin

4. Kozioł A (ed) (1994) Faculty of chemistry. UMCS, Lublin

5. History. http://www.radiochemistry.umcs.lublin.pl

6. Komosa A, Solecki J, Szczypa J (1978) J Appl Chem Biotechnol 28:844-846

7. Solecki J, Komosa A, Szczypa J (1979) Int J Miner Process 6:221228

8. Szczypa J, Solecki J, Komosa A (1980) J Miner Process 7:151-157

9. Janusz W, Komosa A, Monies A, Szczypa J (1987) Physicochem Probl Miner Process 19:125-133 
10. Janusz W, Monies A, Komosa A, Szczypa J (1988) In: Proceedings of the 16th international mineral processing congress, Stockholm, pp 1155-1161

11. Janusz W, Szymula M, Szczypa J (1983) Int J Miner Process 11:79-88

12. Szczypa J, Chibowski S, Kuśpit K (1979) Miner Process Extr Metall Trans Inst Min Metall Sect C 88:C11-C14

13. Chibowski S, Szczypa J, Świta E (1979) Pol J Chem 53:2313-2317

14. Szczypa J, Chibowski S (1981) Colloid Surf 3:393-398

15. Chibowski S, Szczypa J (1982) Pol J Chem 56:359-365

16. Chibowski S, Szczypa J (1984) J Colloid Interface Sci 100:571-572

17. Chibowski S, Szczypa J (1987) Pol J Chem 61:171-176

18. Szczypa J, Hruzewicz J, Sprycha R, Janusz W (1977) Environ Protect Eng 91-101

19. Neczaj-Hruzewicz J, Sprycha R, Janusz W, Szczypa J, Monies A (1979) In: Proceedings of the 13th international mineral processing congress, vol B. Warsaw, pp 2018-2033

20. Szczypa J, Neczaj-Hruzewicz J, Janusz W, Sprycha R (1980) Proc Int Symp AIME 2:1676-1686

21. Szczypa J, Sprycha R, Janusz W (1985) Coal Prep 1:251-257

22. IAEA (1999) International nuclear event scale. IAEA, Vienna. http://www.iaea.org/Publications/Factsheets/English/ines-e.pdf

23. IAEA (2006) Environmental consequences of the Chernobyl accident and their remediation: twenty years of experience. IAEA radiological assessment reports series 1239. IAEA, Vienna

24. Zheltonozhsky V, Mueck K, Bondarkov M (2001) J Environ Radioact 57:151-166

25. Nuclear Energy Agency (2002) Chernobyl. Assessment of radiological and health impact. 2002 update of Chernobyl: ten years on. OECD, Paris

26. Komosa A, Dębczak A, Kitowski I (2007) Global J Environ Res $1: 63-68$

27. Szczypa J, Chibowski S, Solecki J, Suprynowicz R (1993) Pol J Soil Sci 26:27-34

28. Chibowski S, Solecki J, Szczypa J, Suprynowicz R (1994) Sci Total Environ 158:71-77

29. Chibowski S, Solecki J, Szczypa J, Suprynowicz R (1994) Pol J Environ Stud 3:21-25

30. Solecki J, Szczypa J, Chibowski S (1995) Pol J Environ Stud 4:49-52

31. Chibowski S, Solecki J, Szczypa J (1997) J Radioanal Nucl Chem 220:183-190

32. Solecki J, Chibowski S, Szczypa J (1997) Pol J Environ Stud 6:29-32

33. Komosa A (1996) Sci Total Environ 188:59-62

34. Komosa A (1999) Pol J Environ Stud 8:155-160

35. Chibowski S, Pawlik M (1995) Pol J Environ Stud 4:17-23

36. Chibowski S, Zygmunt J (1995) Pol J Environ Stud 4:25-32

37. Chibowski S, Solecki J, Bystrek J (1998) J Radioanal Nucl Chem 230:319-322

38. Komosa A, Chibowski S, Orzeł J (2001) Nukleonika 46:151155

39. Komosa A, Chibowski S, Orzeł J (2002) In: Isajenko K, Lipiński $\mathrm{P}$ (eds) Proceedings of the 3rd international meeting low-level air radioactivity monitoring, Dąbrówno. CLOR, Warsaw

40. Komosa A, Chibowski S (2002) J Radioanal Nucl Chem 251:113-117

41. Vaupotič J, Szymula M, Solecki J, Chibowski S, Kobal I (1993) Health Phys 64:420-422

42. Chibowski S, Komosa A (2001) J Radioanal Nucl Chem 247:53-56

43. Komosa A, Madej E, Piekarz M (2008) Determination of a supported radon activity concentration in bottled mineral waters. Chem Anal (Warsaw) 53:835-843

44. Chibowski S, Mitura A (1995) Sci Total Environ 170:193-198

45. Zygmunt J, Chibowski S, Klimowicz Z (1997) Pol J Environ Stud 6:57-60

46. Komosa A (1999) J Radioanal Nucl Chem 240:19-24
47. Chibowski S, Komosa A, Reszka M, Solecki J, Zygmunt J (2000) J Radioanal Nucl Chem 246:199-206

48. Chibowski S, Komosa A, Reszka M, Solecki J, Zygmunt J (2002) Migration of radionuclides in soils and their accumulation in sediments of superficial waters. IAEA-TECDOC-1314. Radionuclide transport dynamics in freshwater resources. IAEA, Vienna, pp 105-126

49. Solecki J, Chibowski S (2002) Pol J Environ Stud 11:157-163

50. Komosa A (2003) Ann Pol Chem Soc 2:761-764

51. Komosa A, Piekarz M (2009) In: Eikenberg J, Jäggi M, Beer H, Baehrle H (eds) LSC 2008 advances in liquid scintillation spectrometry. Radiocarbon, Tucson, pp 321-329

52. Ziembik Z, Dołhańczuk-Śródka A, Komosa A, Orzeł J, Wacławek M (2010) Water Air Soil Pollut 206:307-320

53. Komosa A, Piekarz M (2010) Nukleonika 55:137-141

54. Komosa A (2002) J Radioanal Nucl Chem 252:121-128

55. Komosa A, Gascó C, Alvarez A, Navarro N, Antón MP, Orzeł J, Michalik S (2005) In: Chałupnik S, Schőnhofer F, Noakes J (eds) Proceedings of the international conference LSC 2005 advances in liquid scintillation spectrometry, Katowice. Radiocarbon, Tucson, pp 285-296

56. Tessier A, Campbell PGG, Bisson M (1979) Anal Chem 51:844851

57. Rauret G (1998) Talanta 46:449-455

58. Komosa A, Kitowski I, Ślepecka K (2007) Ecol Chem Eng $8: 805-818$

59. Komosa A, Kitowski I (2008) Ecol Chem Eng S 15:349-358

60. Komosa A, Kitowski I, Chibowski S, Solecki J, Orzeł J, Różański P (2009) J Radioanal Nucl Chem 281:467-478

61. L'Annunziata MF, Kessler J (1998) In: L'Annunziata MF (ed) Handbook of radioactivity analysis. Academic, London, pp 209239

62. Komosa A, Ślepecka K (2009) In: Eikenberg J, Jäggi M, Beer H, Baehrle H (eds) LSC 2008 advances in liquid scintillation spectrometry. Radiocarbon, Tucson, pp 161-172

63. Komosa A, Ślepecka K (2010) Nukleonika 55:155-161

64. IAEA (1989) Measurements of radionuclides in food and the environment. A guidebook. IAEA technical report series 295. IAEA, Vienna

65. Haque MA, Nakanishi T (1999) J Radioanal Nucl Chem 239:565569

66. Solecki J (2007) J Radioanal Nucl Chem 274:27-38

67. Solecki J, Chibowski S (2001) J Radioanal Nucl Chem 247:165-169

68. Solecki J, Reszka M, Chibowski S (2006) Nukleonika 51(Suppl 2):S33-S37

69. Solecki J, Reszka M, Chibowski S (2003) J Radioanal Nucl Chem 257:261-265

70. Mietelski JW (2003) Nuclear spectrometry in bioavailability studies of fuel like "hot-particles" in forest environment. Nuclear Physics Institute report 1921/B. Nuclear Physics Institute, Kraków

71. Chibowski S, Zygmunt J, Klimowicz Z (1999) J Radioanal Nucl Chem 242:287-295

72. Chibowski S, Reszka M (2001) J Radioanal Nucl Chem 247:443-446

73. Komosa A, Kitowski I, Ślepecka K (2007) Ecol Chem Eng 14:805-818

74. Komosa A, Chibowski S, Kitowski I, Krawczyk R, Orzeł J, Reszka M (2006) J Radioanal Nucl Chem 269:195-201

75. Mietelski JW, Kitowski I, Gaca P, Grabowska S, Tomankiewicz E, Szwałko P (2006) J Radioanal Nucl Chem 270:131-135

76. Komosa A (1999) Pol J Environ Sci 8:155-160

77. Komosa A (2002) In: Mőbius S, Noakes J, Schőnhofer F (eds) Proceedings of the international conference LSC 2001 advances in liquid scintillation spectrometry. Radiocarbon, Tucson, pp $363-371$ 


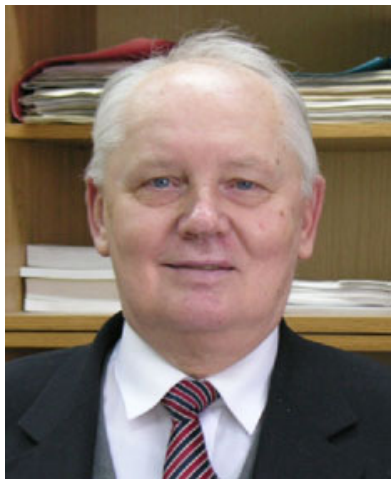

Wladysław Rudziński is head of the Department of Theoretical Chemistry and professor at the Maria Curie Sklodowska University in Lublin. Since 1999 he has also been the head of the Laboratory for the Theoretical Problems of Adsorption of the Institute of Catalysis and Surface Chemistry of the Polish Academy of Sciences in Cracow. He was also the Chairman of the Committee for Interface Chemistry of the Polish Chemical Society, and served also one year as the President of the Society. W.

Rudziński was a member of the Board of Directors of the International Adsorption Society, and served as a member of the Scientific Committees of such international conferences as the largest world conference on adsorption FOA (Fundamentals of Adsorption), or the Pacific Adsorption Conference. He is also a corresponding member of the European Academy of Arts, Sciences and Humanities. He is a member of the editorial boards of Adsorption, and of Adsorption Science \& Technology.

For his outstanding scientific achievements, he has been honored five times by the Polish Ministry of Education and once by the Rector of Maria Curie-Sklodowska University. He was also awarded the Medal of Honor of the Polish Chemical Society.

His main scientific research interests are the theoretical description of adsorption of simple ions and of surfactants at oxide/electrolyte interfaces (special attention focused on enthalpies of adsorption and on effects of surface heterogeneity), equilibria and kinetics of gas adsorption on energetically heterogeneous solid surfaces, (also thermodesorption), and mixed-gas adsorption.

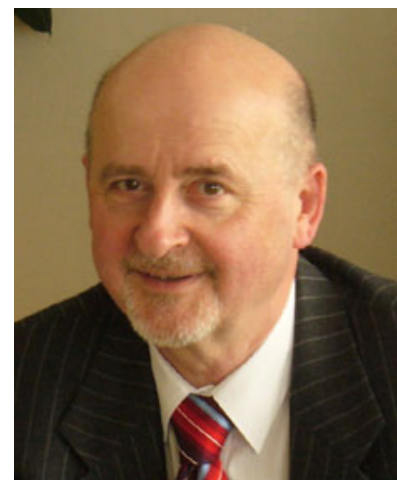

Andrzej Komosa is assistant professor at the Department of Radiochemistry and Colloid Chemistry, Faculty of Chemistry, Maria Curie-Sklodowska University since 2004 where he initated his research on radioecology with particular consideration of plutonium isotopes, including beta emitting ${ }^{241} \mathrm{Pu}$. Starting from 2005, he was a scientific manager of two scientific projects supported by the Polish Ministry of Science and Higher Education. He is a member of editorial boards of numerous journals, for example: Advances in Environmental Biology, Journal of Applied Sciences, Journal of Environmental Science and Technology, Research Journal of Environmental Sciences Natural Science, Global Journal of Environmental Research, Journal of Environmental Chemistry and Ecotoxicology.

His scientific interests concern analytical chemistry, radiochemistry, radioecology (especially concerning birds and small mammals), radioisotope and trace element migration in the environment (including heavy metals, natural radioisotopes, radon and artificial radioisotopes resulting from fallout, e.g.. radiocesium), and research into and improvement of analytical methods for determination of radionuclides (especially plutonium and polonium) in environmental samples. For his extensive teaching activities he was awarded the medal of the Polish National Commission of Education in 2004. 